\title{
EVALUATION OF THE BLEACHED HUMAN ENAMEL BY SCANNING ELECTRON MICROSCOPY
}

\author{
AVALIAÇÃO DO ESMALTE DENTAL HUMANO SUBMETIDO AO TRATAMENTO \\ CLAREADOR POR MEIO DE MICROSCOPIA ELETRÔNICA DE VARREDURA
}

\author{
Carolina Baptista MIRANDA ${ }^{1}$, Clovis PAGANI ${ }^{2}$, Ana Raquel BENETTI ${ }^{1}$, Fábio da Silva MATUDA ${ }^{3}$
}

\begin{abstract}
1- DDS, MSc, Graduate student (Master degree), Department of Restorative Dentistry, São José dos Campos School of Dentistry - UNESP. 2- DDS, MSc, PhD, Associate Professor, Department of Restorative Dentistry, São José dos Campos School of Dentistry - UNESP. 3- DDS, MSc, PhD, Graduate student (Doctor degree), Department of Restorative Dentistry, São José dos Campos School of Dentistry - UNESP.

Corresponding address: Carolina Baptista Miranda - Rua Guillard Muniz, 75 apto. 1301 - Pituba - Salvador / BA Cep.: 41810-110 Fone: (071) 3451-7992 ou 8114-5536 - carolinabmiranda@superig.com.br
\end{abstract}

Received: March 15, 2004 - Modification: May 12, 2004 - Accepted: September 28, 2004

\begin{abstract}
S

Since bleaching has become a popular procedure, the effect of peroxides on dental hard tissues is of great interest in research. Purpose: The aim of this in vitro study was to perform a qualitative analysis of the human enamel after the application of in-office bleaching agents, using Scanning Electron Microscopy (SEM). Materials and Methods: Twenty intact human third molars extracted for orthodontic reasons were randomly divided into four groups $(\mathrm{n}=5)$ treated as follows: G1- storage in artificial saliva (control group); G2- four 30-minute applications of $35 \%$ carbamide peroxide (total exposure: 2h); G3- four 2-hour exposures to 35\% carbamide peroxide (total exposure: 8h); G4- two applications of 35\% hydrogen peroxide, which was light-activated with halogen lamp at $700 \mathrm{~mW} / \mathrm{cm}^{2}$ during $7 \mathrm{~min}$ and remained in contact with enamel for $20 \mathrm{~min}$ (total exposure: 40min). All bleaching treatments adopted in this study followed the application protocols advised by manufacturers. Evaluation of groups submitted to 35\% carbamide peroxide was carried out after two time intervals (30 minutes and 2 hours per session), following the extreme situations recommended by the manufacturer. Specimens were prepared for SEM analysis performing gold sputter coating under vacuum and were examined using 15kV at 500x and 2000x magnification. Results: Morphological alterations on the enamel surface were similarly detected after bleaching with either 35\% carbamide peroxide or 35\% hydrogen peroxide. Surface porosities were characteristic of an erosive process that took place on human enamel. Depression areas, including the formation of craters, and exposure of enamel rods could also be detected. Conclusion: Bleaching effects on enamel morphology were randomly distributed throughout enamel surface and various degrees of enamel damage could be noticed. Clinical significance: In-office bleaching materials may adversely affect enamel morphology and therefore should be used with caution. Uniterms: Hydrogen peroxide; Carbamide peroxide; Tooth bleaching.
\end{abstract}

\section{RESUMO}

D

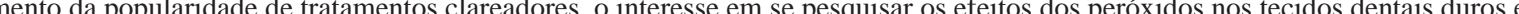
crescente. Proposta: O objetivo deste trabalho foi conduzir uma análise qualitativa in vitro do esmalte dental humano após clareamento com agentes para consultório, por meio de Microscopia Eletrônica de Varredura (MEV). Material e métodos: Foram utilizados 20 terceiros molares humanos hígidos, extraídos por motivos ortodônticos, sendo aleatoriamente divididos em 4 grupos $(\mathrm{n}=5)$ e tratados da seguinte forma: G1armazenamento em saliva artificial (grupo controle); G2- 4 aplicações de peróxido de carbamida a 35\% por 30 min (tempo total de aplicação: 2h); G3- 4 aplicações de peróxido de carbamida a 35\% por 2 h (tempo total de aplicação: 8h); G4- 2 aplicações de peróxido de hidrogênio a 35\%, que foi foto-ativado com lâmpada halógena a $700 \mathrm{~mW} / \mathrm{cm}^{2}$ por 7 min e mantido em contato com o dente durante 20 min (tempo total de aplicação: 40min). A avaliação dos grupos submetidos ao clareamento com peróxido de carbamida a 35\% após 2 tempos de aplicação (30 minutos e 2 horas por sessão) para testar as situações extremas recomendadas pelo fabricante. As amostras foram recobertas com ouro para análise em MEV e foram examinadas utilizando 15kV e aumentos de 500x e 2000x. Resultados: Foram detectadas alterações morfológicas similares na superfície do esmalte após o clareamento com peróxido de carbamida a 35\% e peróxido de hidrogênio a 35\%. Porosidades e irregularidades caracterizando um processo erosivo foram observadas no esmalte humano. Áreas de depressão, incluindo a formação de crateras e exposição dos prismas de esmalte também foram observadas. Conclusão: Os efeitos do clareamento na morfologia do esmalte encontraram-se distribuídos aleatoriamente por toda a superfície do esmalte e danos em diferentes intensidades puderam ser evidenciados. Significância clínica: Agentes concentrados para clareamento em consultório podem comprometer a morfologia do esmalte e, portanto, devem ser utilizados com cautela.

Unitermos: Peróxido de hidrogênio; Peróxido de carbamida; Clareamento de dente. 


\section{INTRODUCTION}

Esthetics has strongly influenced patient's perceptions and appealed to the development and expansion of the cosmetic industry. Inevitably, the request of whiter teeth has become a major concern in dental practice since discoloration of a single tooth or a group of teeth negatively interferes with the harmony of smile. Although tooth color is only one of the aspects involved in facial harmony, it represents the most important isolated factor because it is immediately noticed ${ }^{1}$.

Esthetic dentistry has introduced various corrective measures to treat discolored teeth, such as laminate veneers, direct resin restorations, crowns or fixed prostheses. Dental bleaching represents a conservative treatment option or may become an auxiliary therapy when restorative procedures are required to eliminate color abnormalities ${ }^{2}$.

Bleaching agents are provided for in-office or at-home therapies. In-office bleaching requires less patient's cooperation, but longer sessions are necessary in the dental office, which increases the treatment costs. Otherwise, athome bleaching is less expensive, but patient's collaboration is essential to obtain successful treatment results ${ }^{3}$.

Hydrogen peroxide is the main active ingredient of bleaching agents and the whitening effect it produces is due to its low molecular weight and its ability to penetrate through enamel and dentin ${ }^{1,4}$. The basic process involves oxidation and reduction reactions that convert organic pigments into carbon dioxide and water ${ }^{1,5}$. Carbamide peroxide decomposes into urea and hydrogen peroxide ${ }^{5}$. Therefore, products containing the same concentration but different active ingredients are expected to behave differently on dental hard tissues. Such behavior might become even more evident when considering regular or light-activated gels or distinct exposure periods.

Although dental hard tissues are highly mineralized, their organic content can play an important role in the bleaching process. It is speculated that the reaction between peroxide and organic materials on the surface or in the subsurface of enamel can result in morphological alterations ${ }^{6}$.

Despite the advantages offered by the bleaching treatment, the effect of bleaching agents on dental hard tissues is rather controversial. Some studies have demonstrated no significant effects of bleaching agents on human enamel ${ }^{4,7}$. Contrary results have shown morphological alterations on bleached enamel, thus suggesting an erosive process ${ }^{8,9,10,11}$.

Since bleaching has been widely advocated by dental professionals, the effect of bleaching agents on dental hard tissues is of great interest in research. Therefore, the purpose of this in vitro study was to investigate the influence of inoffice bleaching agents on human enamel morphology, comparing 35\% carbamide peroxide or 35\% light-activated hydrogen peroxide.

\section{MATERIALS AND METHODS}

This study was developed in accordance with the Code of Ethics in Research (n063/2001 PH/CEP). Twenty intact human third molars extracted for orthodontic reasons were selected for this study. Immediately after extraction, periodontal tissue was removed and teeth were stored in saline solution at $-20^{\circ} \mathrm{C}$ for a maximum period of 28 days ${ }^{12}$. Prior to group division, teeth were examined at a stereomicroscope Stemi 2000 (Carl Zeiss, Jena, Germany) at 20x magnification to select teeth without cracks or structural defects that could compromise the results of the study.

All teeth were submitted to mesio-distal crosscut sections to separate buccal and lingual fragments. Horizontal sections were performed at the cementoenamel junction, separating coronary and root pieces. Buccal sections were selected for the SEM analysis and randomly divided into four groups of five specimens each, treated as follows:

- Group 1: no bleaching treatment was performed. All buccal sections were kept in artificial saliva at $37^{\circ} \mathrm{C}$ until SEM analysis was performed.

- Group 2: buccal sections were placed in contact with 35\% carbamide peroxide (Opalescence Quick, batch \#479B, Ultradent, South Jordan, Utah, United States), facing a Petri dish containing the gel. Product was heated in warm water prior to use, following the manufacturer's recommendation. Specimens were kept in contact with the bleaching agent for 30 minutes. Next, specimens were rinsed with distilled water and stored in artificial saliva at $37^{\circ} \mathrm{C}$. This procedure was repeated weekly in four applications (total exposure: 2h).

- Group 3: bleaching protocol followed steps determined for group 3, but adopting a longer exposure period. Twohour applications of 35\% carbamide peroxide (Opalescence Quick, batch \#479B, Ultradent, South Jordan, Utah, United States) were performed weekly for four weeks (total exposure: $8 \mathrm{~h})$. Variation in the exposure period was determined since the manufacturer suggested a minimum of 30-minute and maximum of 2-hour exposure. Therefore, minimum time exposure was investigated in group 2 while maximum exposure period was evaluated in group 3.

- Group 4: two 20-minute applications of 35\% hydrogen peroxide (Opalescence X-tra, batch \#532B, Ultradent, South Jordan, Utah, United States) were performed in accordance to manufacturer's recommendation. Gel was applied on enamel specimens and light-activation was performed initially for 5 minutes. The light source used was Curing Light XL3000 (3M ESPE) at 700mW/cm². Four extra 30second light-activations were carried out every $3.5 \mathrm{~min}$ during the 15-minute period that the gel remained in contact with enamel. Therefore, total light activation was performed for 7 minutes during gel contact of 20 minutes. Teeth were rinsed with distilled water to remove the gel and bleaching protocol was repeated (total exposure: 40 minutes).

After carrying out bleaching protocols, teeth were rinsed and stored in artificial saliva at $37^{\circ} \mathrm{C}$ for 24 hours. The artificial saliva contained calcium chloride $(0.16 \mathrm{~g})$, sodium benzoate (1g), carboxymethyl cellulose (10g), magnesium chloride 
(0.05g), potassium chloride $(0.62 \mathrm{~g})$, sodium chloride $(0.82 \mathrm{~g})$, sodium fluoride (4.29g), sorbitol (42.74g), potassium phosphate $(1.12 \mathrm{~g})$, and distilled water up to $100 \mathrm{ml}$. Teeth were rinsed thoroughly prior to SEM investigation.

\section{Scanning Electron Microscopy (SEM) investigation}

Twenty-four hours after bleaching, specimens were dehydrated in ascending grades of ethanol. Twenty-minute immersion in each solution was performed at concentrations of $50 \%, 60 \%, 70 \%, 80 \%$, and $90 \%$ ethanol. Sixty-minute immersion in $100 \%$ ethanol was carried out. Specimens dried at room temperature during 12 hours. Crowns were fixed in aluminum stubs and then sputter-coated with goldpalladium (Desk II, Denton Vacuum, Moorestown, NJ, United States) during 2 minutes.

Enamel surface was examined at 500x and 2000x magnification with scanning electron microscope (JMS 5310, JEOL, Tokyo, Japan), using $15 \mathrm{kV}$. A scanning of the entire buccal surface was performed and most critical areas were selected for scanning electron microscope photomicrographs.

\section{RESULTS}

Figure 1 depicts unbleached enamel. Although the surface is not completely smooth, uniformity of the aprismatic surface layer can be observed. Pores and superficial irregularities were also present.

Effects of bleaching were randomly distributed on enamel surface after the application of in-office products (Figures 2, 3, 4, and 5). In fact, different types of defects and distinct severity of such events could be observed throughout the enamel surface. Modification of enamel morphology was detected either after 35\% carbamide peroxide (Figures 2 and 3) or 35\% hydrogen peroxide applications (Figures 4 and 5). In general, it seems that bleaching evidenced original irregularities present on enamel surface. Morphologic surface alterations became much more pronounced after bleaching, including partial removal of the aprismatic layer, increased depth of enamel grooves, and exposure of the enamel prisms (Figures 2B, 4A, 4B and 5B). An increased number of porosities on enamel surface could be noticed (Figures 2A and 5A), when compared to the control group (Figure 1). Intermittent depressions of various depths were present (Figures 3A, 3B, 4A and 5B); craters (Figure 2B), and shallow erosions (Figures $2 \mathrm{~A}$ and $5 \mathrm{~A}$ ) could also be observed.

Similar observations were detected on enamel morphology of teeth treated with either conventional carbamide peroxide gel or light-activated hydrogen peroxide. It must be emphasized, however, that the irregularities found on enamel surface were more frequently distributed in the experimental groups, but were also detected on the unbleached enamel.

\section{DISCUSSION}

Effects of bleaching agents on enamel surface have been discussed recently. When considering in-office bleaching agents, controversial results have been reported. Thirtyfive percent hydrogen peroxide applications did not produce morphological alterations on enamel in research conducted by Ernst, el al. ${ }^{7}$. Likewise, Gultz, et al. ${ }^{13}$, who adopted the same methods of this study and tested the same bleaching agents (Opalescence Quick and Opalescence X-tra), did not report significant alterations on the enamel surface. However, exposure periods determined in their study were shorter (total exposures of 2 hours for 35\% carbamide peroxide and
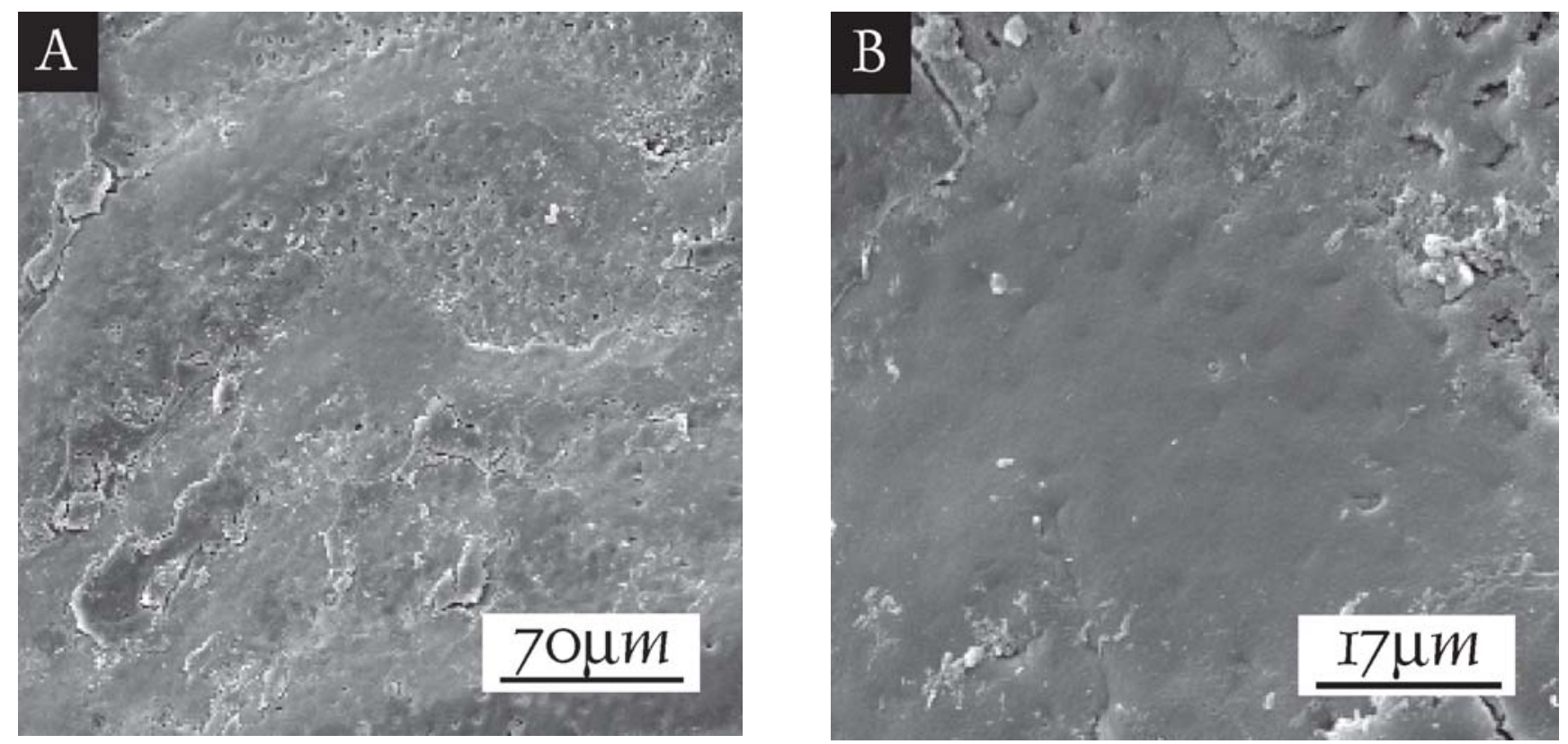

FIGURE 1- Photomicrographs of unbleached enamel (control group) at 500x (A) and 2000x magnifications (B) 
8 to 10 minutes for 35\% light-activated hydrogen peroxide) than those stipulated for this investigation (total exposures of 2 or 8 hours for 35\% carbamide peroxide and 40 minutes for $35 \%$ light-activated hydrogen peroxide).

In this study, defects could be randomly detected on the enamel surface with distinct severity after bleaching. Similar behavior has been reported in previous studies, even after $10 \%$ carbamide peroxide bleaching, which releases lower amounts of hydrogen peroxide when compared to in-office bleaching agents. Surface erosion ${ }^{9}$, depressions ${ }^{14}$, porosity, and increased depth of enamel grooves ${ }^{6}$ were some of the alterations mentioned.

More severe alterations could be expected on enamel surface after in-office bleaching. Increased porosity ${ }^{14,15}$ and precipitate deposition ${ }^{16}$ characterized enamel erosion ${ }^{9,17,18}$.
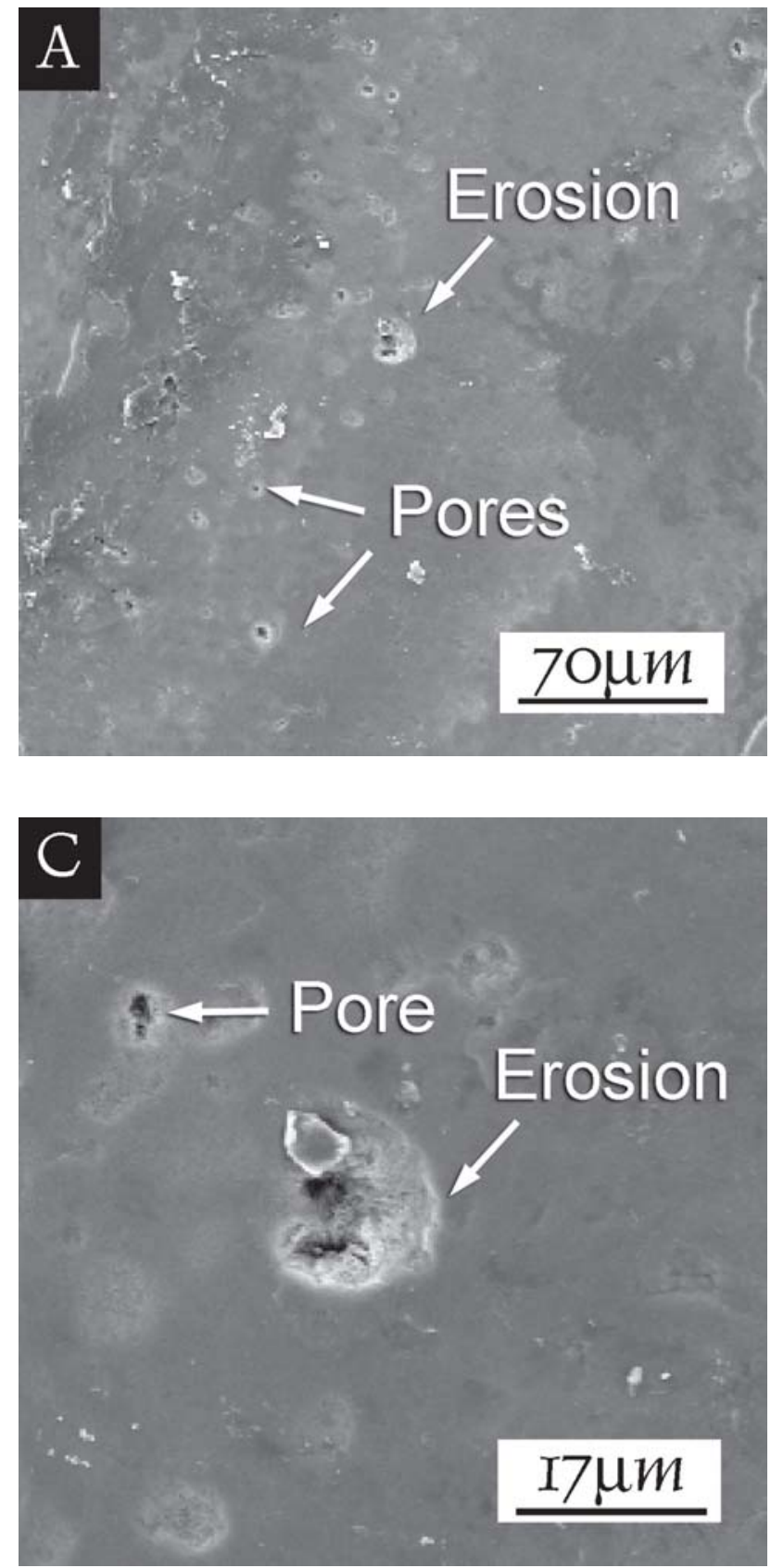

Depressions $^{6,19}$ with crater formation, removal of the aprismatic layer and exposure of the enamel prisms ${ }^{15,17}$ could also be detected. Hegedüs, et al. ${ }^{6}$ detected a pronounced increase in the depth of enamel grooves after 30\% hydrogen peroxide bleaching. McGuckin, et al. ${ }^{19}$ reported morphological alterations on enamel surface, describing enamel patterns similar to type II acid etching, after 30\% hydrogen peroxide applications.

Although 35\% hydrogen peroxide presents higher concentration of free hydrogen peroxide when compared to $35 \%$ carbamide peroxide gel, no visual difference was detected between groups treated with such products. Similar results were probably observed due to the shorter exposure periods and fewer sessions determined for the light-activated gel.
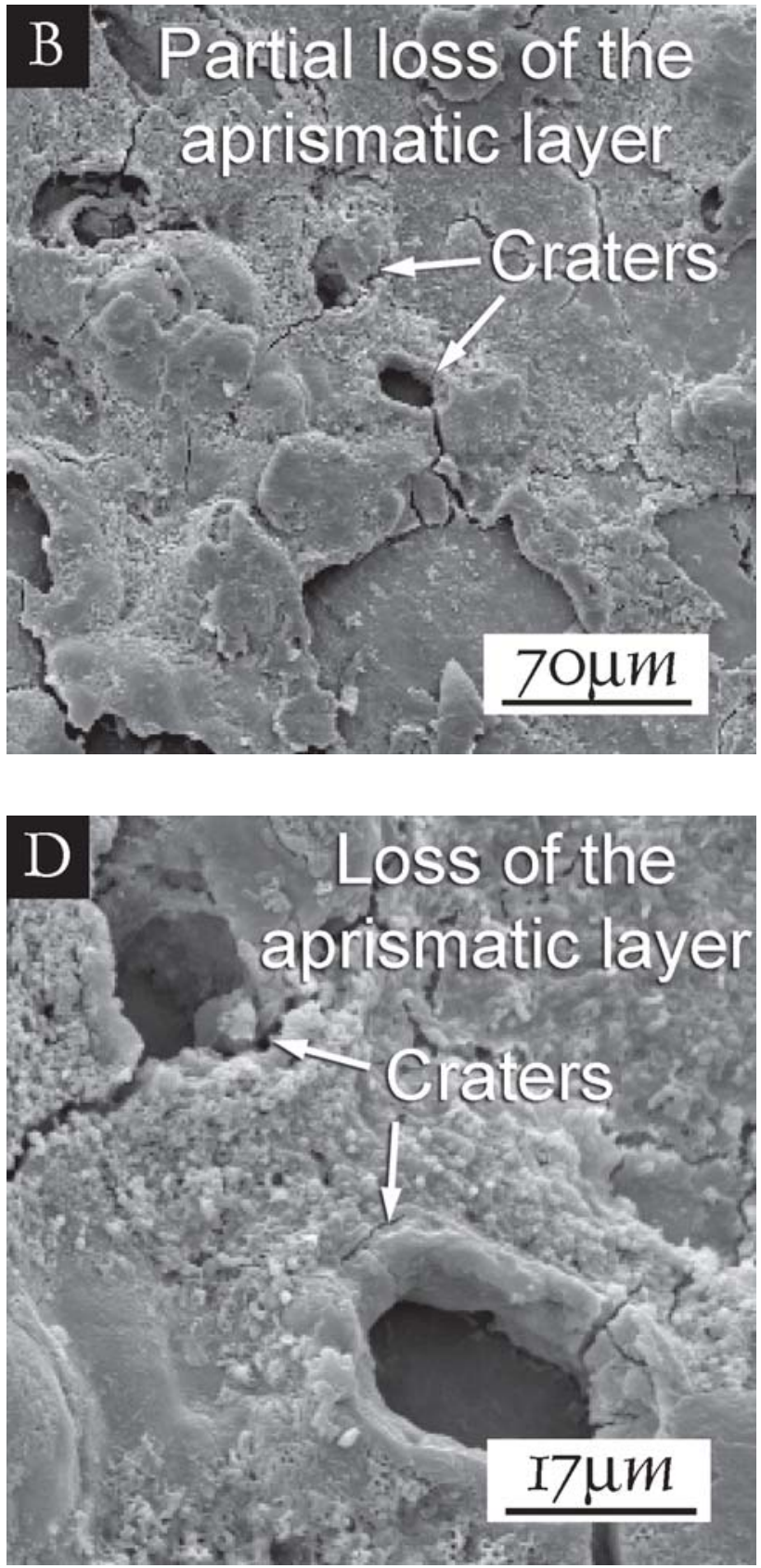

FIGURE 2- Photomicrographs of bleached enamel after 35\% carbamide peroxide applications at 500x (A and B) and 2000x magnifications (C and D): removal of the aprismatic layer, craters, pores, and erosion 
Authors believe that enamel alterations are probably due to an initial process of demineralization. McCracken and Haywood ${ }^{20}$ and Rotstein, et al. ${ }^{21}$ have proven loss of calcium in teeth exposed to peroxide. Rotstein, et al. ${ }^{22}$ observed lower resistance and higher solubility of dental hard tissues after bleaching procedures, possibly due to modification of the organic and inorganic ratio of the tissues. Oltu and Gürgan ${ }^{23}$ observed changes in the inorganic composition of the bleached enamel after 35\% carbamide peroxide exposure. Indeed, most bleaching agents are acidic, which is not favorable to enamel, dentin, and cement. The $\mathrm{pH}$ of bleaching agents investigated in this study was 6.4 and 3.8 for 35\% carbamide peroxide (Opalescence Quick) and $35 \%$ hydrogen peroxide (Opalescence X-tra), respectively.
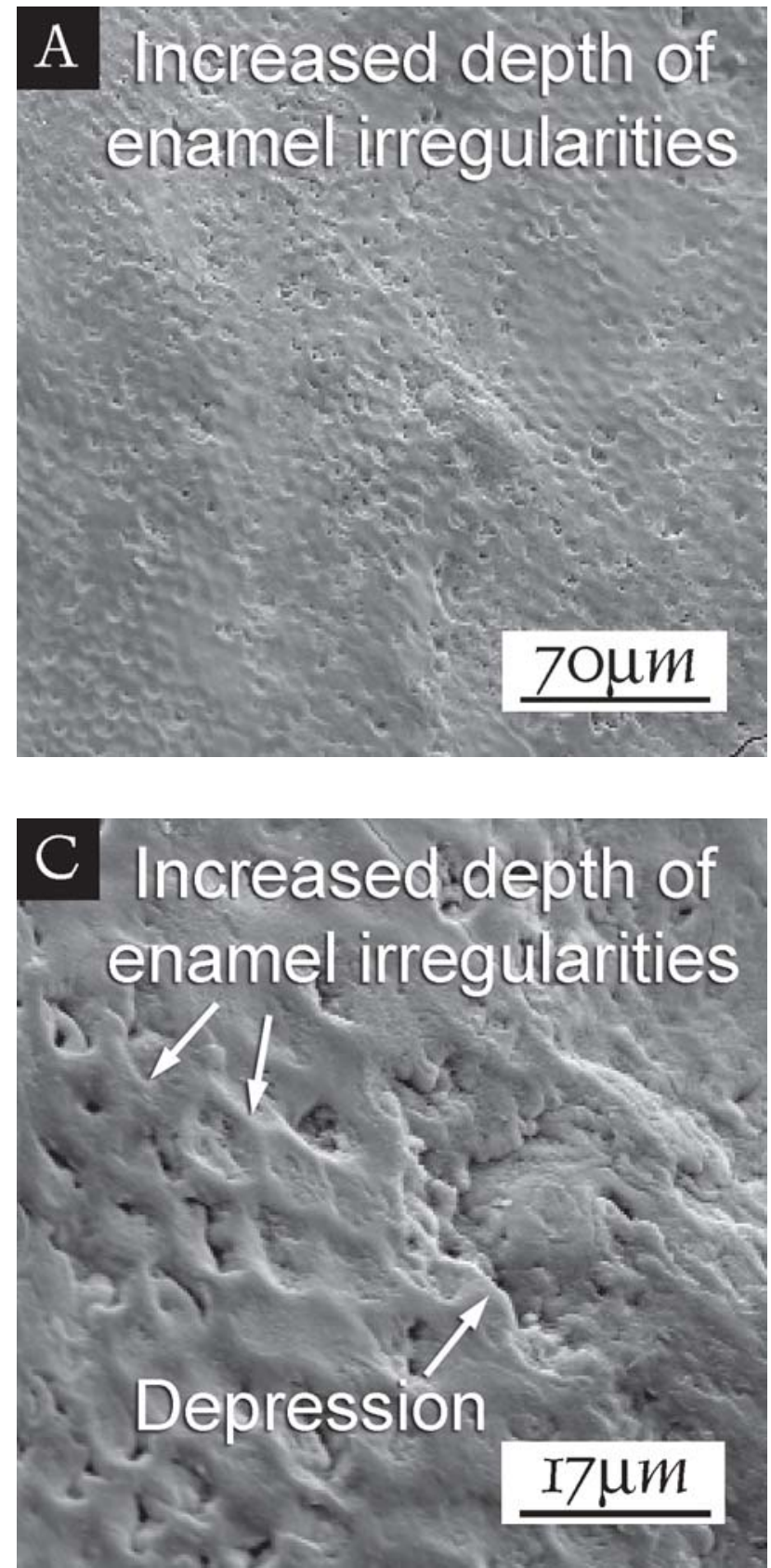

Although artificial saliva was used in this study to simulate oral conditions, its remineralization potential is not equivalent to natural saliva in vivo. Fewer alterations are expected in vivo, due to the buffer capacity of saliva. Rodrigues, et al. ${ }^{24}$ reminded that saliva and fluoride ions present in oral care substances are essential to equilibrate the demineralization and remineralization processes. According to Lopes, et al. ${ }^{25}$, $\mathrm{pH}$ values as low as 6.4 may remove minerals from teeth in in vitro situations; thus, artificial saliva might not be able to guarantee remineralization.

In vivo or in vitro bleaching, various concentrations and exposure periods to bleaching agents, use of different substances prior to treatment, sample size, and evaluation criteria are distinct among different research studies. Thus, a comparison between studies becomes rather difficult.
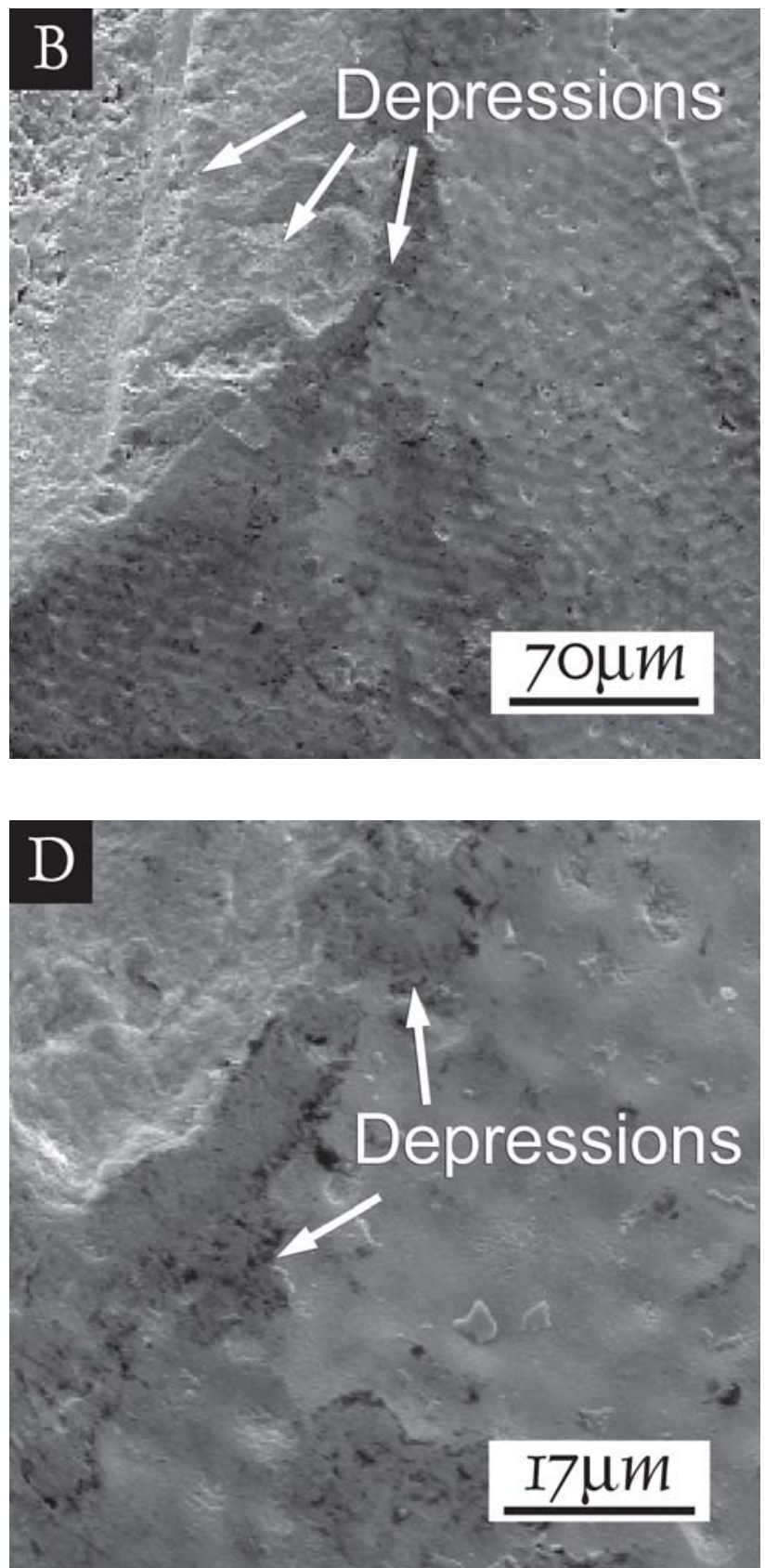

FIGURE 3- Photomicrographs of bleached enamel after 35\% carbamide peroxide applications at 500x (A and B) and 2000x magnifications ( $C$ and $D)$ : depressions and increased depth of enamel irregularities 
However, most papers are in agreement with findings reported in this study, which detected significant changes on the enamel surface after bleaching with concentrated hydrogen or carbamide peroxide. Therefore, caution is required when performing in-office bleaching.

Significant changes in the enamel morphology and microstructure produced by bleaching agents are suggestive of alterations in physical and mechanical properties of dental hard tissues ${ }^{10,25,26,27}$. Indeed, further studies are necessary to completely understand the effects of bleaching agents on dental tissues.
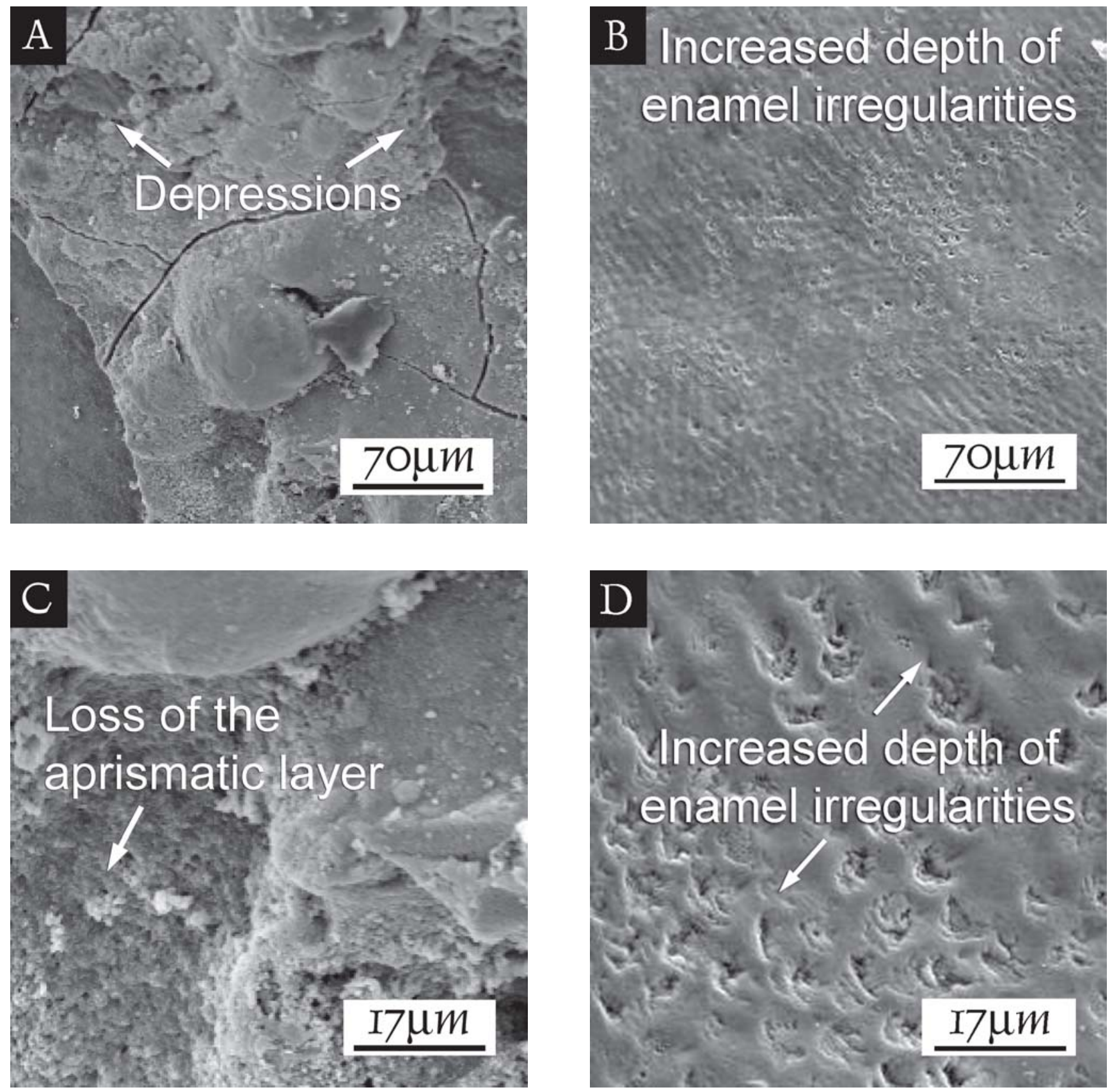

FIGURE 4- Photomicrographs of bleached enamel after 35\% hydrogen peroxide applications at 500x (A and B) and 2000x magnifications ( $C$ and $D$ ): depressions, removal of the aprismatic layer, and increased depth of enamel irregularities
SEM qualitative investigation demonstrated that inoffice bleaching agents affected human enamel morphology, producing porosities, depressions, craters, increased depth of enamel grooves, and partial removal of enamel prisms. These defects were randomly distributed and affected the enamel surface at various degrees.

\section{Clinical implications}

In-office bleaching materials may adversely affect enamel morphology and therefore should be used with caution. 


\section{REFERENCES}

1- Baratieri LN. Clareamento dental. $3^{\text {rd }}$ ed. São Paulo: Quintessence Books; 1993. 176p.

2- Miranda CB, Benetti AR, Pagani C. Inovação no clareamento dental caseiro - Crest Whitestrips: combinação de gel em fitas. J Bras Clin Estet Odontol. 2002;6: 291-4.

3- Papathanasiou A, Bardwell D, Kugel G. A clinical study evaluating a new chairside and take-home whitening system. Compend Contin Educ Dent. 2001;22:289-97.

4- Haywood VB, Leech T, Heymann HO, Crumpler D, Bruggers K. Nightguard vital bleaching: effects on enamel surface texture and diffusion. Quintessence Int. 1990;21:801-4.
5- Haywood VB, Houck V, Heymann HO. Nightguard vital bleaching: effects of various solutions on enamel surface texture and color. Quintessence Int. 1991;22:775-82.

6- Hegedüs C, Bistey T, Flora-Nagy E, Keszthelyi G, Jenei A. An atomic force microscopy study on the effect of bleaching agents on enamel surface. J Dent. 1999;27:509-15.

7- Ernst CP, Marroquin BB, Willershausen-Zönnchen B. Effects of hydrogen peroxide-containing bleaching agents on the morphology of human enamel. Quintessence Int. 1996;27:53-6.

8- Ledoux WR, Malloy RB, Hurst RV, McInnes-Ledoux P, Weinberg R. Structural effects of bleaching on tetracycline-stained vital rat teeth. J Prosthet Dent. 1985;54:55-9.
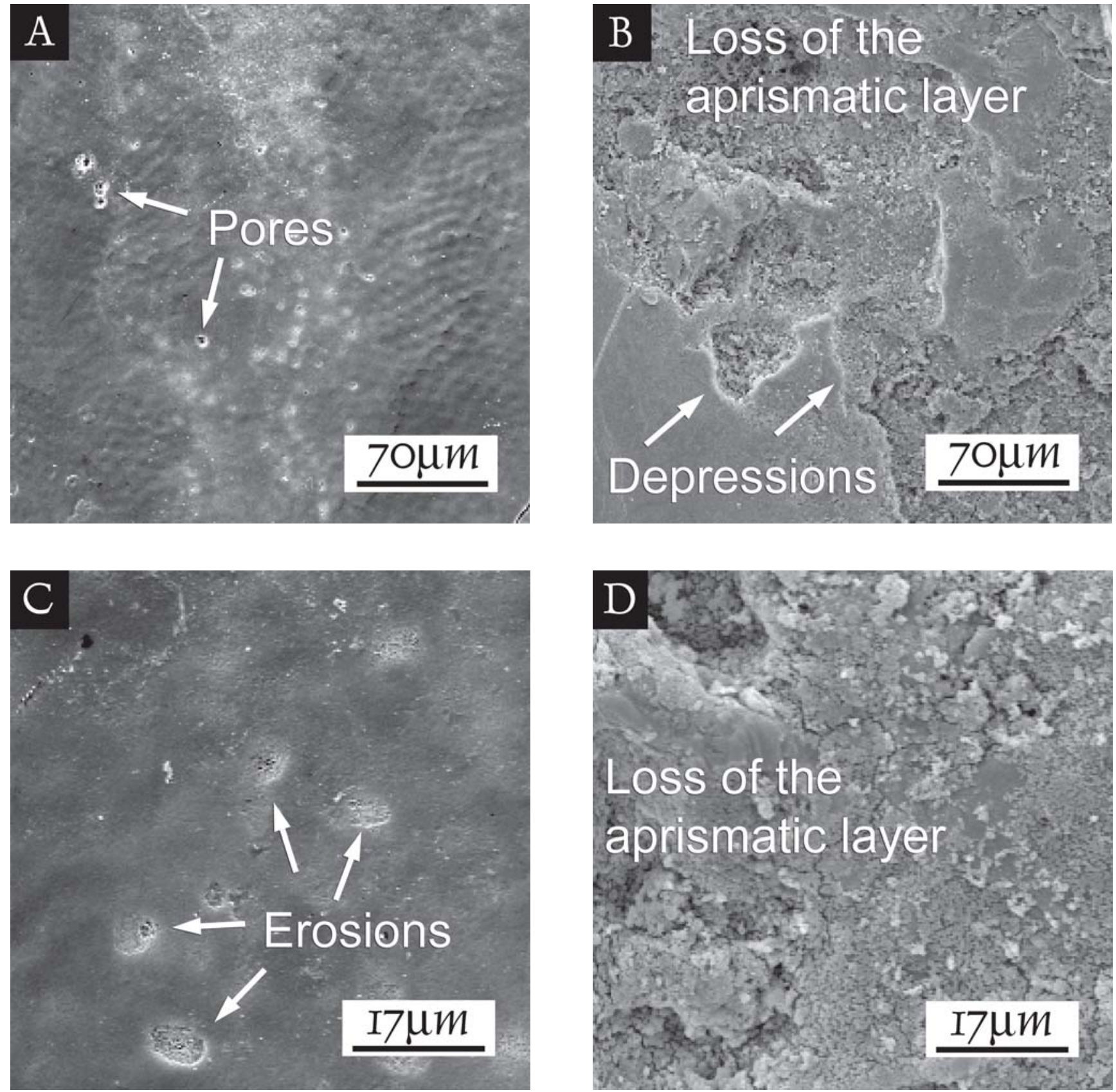

FIGURE 5- Photomicrographs of bleached enamel after 35\% hydrogen peroxide applications at 500x (A and B) and 2000x magnifications (C and $\mathrm{D}$ ): partial removal of the aprismatic layer, pores, depressions and erosions 
9- Covington JS, Friend GN, Lamoreaux WJ, Perry T. Carbamide peroxide tooth bleaching: effects on enamel composition and topography [abstract 530]. J Dent Res. 1990;69(Spec Issue):175.

10- Bitter NC. Scanning electron microscopy study of the effect of bleaching agents on enamel: a preliminary report. J Prosthet Dent. 1992;67:852-5.

11- Shannon H, Spencer P, Gross K, Tira D. Characterization of enamel exposed to $10 \%$ carbamide peroxide bleaching agents. Quintessence Int. 1993;24:39-44.

12- Tonami K, Takahashi H, Nishimura F. Effect of frozen storage and boiling on tensile strength of bovine dentin. Dent Mater J. 1996;15:205-11.

13- Gultz J, Kaim J, Scherer W, Gupta H. Two in-office bleaching systems: a scanning electron microscope study. Compend Contin Educ Dent. 1999;20:965-9.

14- Josey AL, Meyers IA, Romaniuk K, Symons AL. The effect of a vital bleaching technique on enamel surface morphology and the bonding of composite resin to enamel. J Oral Reahabil. 1996;23:24450 .

15- Bitter NC. A scanning electron microscope study of the longterm effect of bleaching agents on the enamel surface in vivo. Gen Dent. 1998;46:84-8.

16- Titley K, Torneck CD, Smith D. The effect of concentrated hydrogen peroxide solutions on the surface morphology of human tooth enamel. J Endod. 1988;14:69-74.

17- Bitter NC, Sanders JL. The effect of four bleaching agents on the enamel surface: a scanning electron microscopic study. Quintessence Int. 1993;24:817-24.

18- Junqueira JC, Colombo CED, Martins CAP, Tavares PG, Araújo MAM, Valera, MC. Efeito da técnica de clareamento, utilizando peróxido de carbamida a 35\%, sobre o esmalte dental: avaliação por microscópio de luz polarizada e microscópio eletrônico de varredura. J Bras Clin Estet Odontol. 2000;4:61-5.

19- McGuckin RS, Babin JF, Meyer BJ. Alterations in human enamel surface morphology following vital bleaching. J Prosthet Dent. 1992;68:754-60.

20- McCracken MS, Haywood VB. Demineralization effects of 10 percent carbamide peroxide. J Dent. 1996;24:395-8.

21- Rotstein I, Dankner E, Goldman A, Heling I, Stabholtz A, Zalkind M. Histochemical analysis of dental hard tissues following bleaching. J Endod. 1996;22:23-5.

22- Rotstein I, Lehr Z, Gedalia I. Effect of bleaching agents on inorganic components of human dentin and cementum. J Endod. 1992;18:290-3.

23- Oltu Ü, Gürgan S. Effects of three concentrations of carbamide peroxide on the structure of enamel. J Oral Rehabil. 2000;27:33240.

24- Rodrigues JA, Basting RT, Serra MC, Rodrigues Junior AL. Effects of $10 \%$ carbamide peroxide bleaching materials on enamel microhardness. Am J Dent. 2001;14:67-71.

25- Lopes GC, Bonissoni L, Baratieri LN, Vieira LC, Monteiro Junior S. Effect of bleaching agents on the hardness and morphology of enamel. J Esthet Restor Dent. 2002;14:24-30.

26- Seghi RR, Denry I. Effects of external bleaching on indentation and abrasion characteristics of human enamel in vitro. J Dent Res. 1992;71:1340-4.
27- Miranda CB. Avaliação da microdureza e tenacidade do esmalte dental humano submetido ao tratamento clareador; São José dos Campos; 2003. 132f. [Dissertação de Mestrado - Faculdade de Odontologia de São José dos Campos, Universidade Estadual Paulista]. 